\title{
A revised checklist of mosquitoes Genus Coquillettidia Dyar, 1905 (Diptera: Culicidae) from Indonesia with key to species
}

\author{
SIDIQ SETYO NUGROHO ${ }^{1, \bullet}$, MUJIYONO ${ }^{1}$, FAHMAY DWI AYUNINGRUM ${ }^{1}$, RIYANI SETIYANINGSIH ${ }^{1}$, \\ UPIEK NGESTI WIBAWANING ASTUTI ${ }^{2}$ \\ ${ }^{1}$ Institute for Vector and Reservoir Control Research and Development. Jl. Hasanudin No. 123, Salatiga 50271, Central Java, Indonesia \\ Tel.: +62-298-327096, Fax.: +62-298-322604, `email: sidiqsnugroho148@ gmail.com. \\ ${ }^{2}$ Division of Parasitology, Laboratory of Animal Systematics, Faculty of Biology, Universitas Gadjah Mada. Jl. Teknika Selatan, Sleman 55281, \\ Yogyakarta, Indonesia
}

Manuscript received: 2 September 2020. Revision accepted: 25 November 2020.

\begin{abstract}
Nugroho SS, Ayuningrum FD, Setyaningsih RS, Astutu UNW. 2020. A revised checklist of mosquitoes Genus Coquillettidia Dyar, 1905 (Diptera: Culicidae) from Indonesia with key to species. Biodiversitas 21: 5772-5777. Mosquito species from Genus Coquillettidia are mostly found in Afrotropic Region, with some species distributed in the Oriental and Australasian Region including Indonesia. Some species are confirmed as the vector for human pathogens. As previous research stated that up to 1981, there were eight species of Coquillettidia that have been on the checklist of mosquitoes in Indonesia. Nowadays, eleven Coquillettidia species present in Indonesia entirely included in Subgenus Coquillettidia. Three species were added to the checklist, namely Cq. fuscopteron Theobald, Cq. novochracea Barraud, and Cq. xanthogaster Edwards. Research and publication about Genus Coquillettidia in Indonesia are still rare, besides that, the identification key of Coquillettidia female mosquito in Indonesia has never been published before. This paper intended to deliver information about the species checklist and distribution of Genus Coquillettidia in Indonesia and provide a species identification key for female mosquitoes.
\end{abstract}

Keywords: Coquillettidia, distribution, identification key, mosquito, species checklist

\section{INTRODUCTION}

The first information regarding the diversity of Coquillettidia mosquitoes in Indonesia was published nearly 40 years ago in the Indonesian mosquito checklist. The checklist states that Indonesia has around 456 species of mosquitoes, and eight of them are in the genus Coquillettidia (O’Connor and Sopa 1981). About five years ago, efforts were made to update data on the diversity of mosquitoes with the National Research on Disease Vector and Reservoir (Rikhus Vektora) in 2015-2018 organized by the National Institute of Health Research and Development (NIHRD), Indonesian Ministry of Health. The study collected mosquitoes from 29 provinces in Indonesia, including those in the genus Coquillettidia.

In general, mosquitoes in the genus Coquillettidia are medium size species, yellowish in color, and have similarities with Mansonia Blanchard mosquitoes as well as several species of Culex Linnaeus mosquitoes and members of tribe Aedini Neveu-Lemaire. The differences with tribe Aedini are the simple tarsal claws and blunt abdomen tip in female mosquitoes (Harbach and Kitching 1998). The difference with Culex mosquitoes lies in the absence of pulvili in the tarsal claws. Moreover, members of the Coquillettidia subgenus are distinguished from species of the tribe Aedini and Mansonia in the absence of post-spiracular setae. Coquillettidia and Mansonia larvae are distinguished from other genera by spiracular apparatus and siphons that develop uniquely to attach to aquatic plants and obtain oxygen from the air-storing tissue (Rattanarithikul et al. 2005).

Previously the status of the genus Coquillettidia was a subgenus in the genus Mansonia (Stone 1963). Belkin (1962) proposed non-formal taxa named 'tribe' in the Culicidae family below the level of the subfamily. According to Belkin (1962), the genus Mansonia is the sole member of the tribe Mansoniini Belkin with two subgenera, namely Coquillettidia and Mansonioides Theobald. Ronderos and Bachmann (1963) proposed the separation of the genus Mansonia into two genera, namely Mansonia and Coquillettidia. Mansonia with two subgenera, namely Mansonia and Mansonioides, while Coquillettidia with two subgenera, namely Coquillettidia and Rhynchotaenia Brèthes. Belkin (1968) added subgenus Austromansonia Belkin with a single member species, Coquillettidia tenuipalpis Edwards. Knight and Stone (1977), in the Catalogue of Mosquito in the World, also treated Coquillettidia and Mansonia as separate genera. A total of 58 species of the genus Coquillettidia have been identified, which belong to three subgenera, i.e., Austromansonia (1 species), Coquillettidia (44 species), and Rhynchotaenia (13 species).

Genus Mansonia and Coquillettidia have fundamental morphological differences. In adult mosquitoes, genus Mansonia has asymmetrical wing scales, while genus Coquillettidia has symmetrical wing scales. At the pupa stage, genus Mansonia has some branched cephalothorax hairs and relatively wide paddles, whereas in genus Coquillettidia, all cephalothorax hairs are unbranched, and 
the paddles are relatively narrow. Genus Mansonia laid their eggs in masses and attached them to under the surface of the leaves of aquatic plants below the water surface, while genus Coquillettidia laid their eggs like a raft on the water surface (Belkin 1962).

Species of the subgenus Coquillettidia are limited in Old World (Africa, Asia, Australia, and Europe), except for Cq. perturbans Walker in North America. Species of the subgenus Coquillettidia are generally distributed in the Afrotropic Region, but some species are spread in the Oriental and Australasian regions. Two species are found in the Palaearctic region namely $C q$. crassipes van der Wulp and Cq. ochracea Theobald (Belkin 1962).

Bionomics of most mosquito species in the subgenus Coquillettidia are very little known. The immature stages of Coquillettidia are commonly found attached to the roots of aquatic plants in ponds, lakes, swamps, marshes, ditches, wells, ground pools, and flood pools in forest swamps. Female mosquitoes will readily bite humans and active during day and night time (Wharton 1962).

Some species in the subgenus Coquillettidia are pests for humans and livestock in Africa, Europe, and South America. For example, Cq. perturbans is a vector for the eastern equine encephalitis virus and the Tensaw virus in North America (Turell et al. 2005). Meanwhile, Cq. aurites Theobald, Cq. metallica Theobald, and Cq. pseudoconopas Theobald were important vectors for bird malaria in Africa (Njabo et al. 2009). Coquillettidia crassipes is the only species in the genus Coquillettidia that has known as a vector of human disease. Chiang et al. (1986) say that in high population density in Peninsular Malaysia these species become a secondary vector for Brugian filariasis. In West Irian, $C q$. crassipes was incriminated as rural bancroftian filariasis (Hoedojo 1989). Population density of Cq. crassipes increased during periods of low rainfall and captures harbored only Cardiofilaria sp., an avian filarioid, in Tanah Intan, South Borneo (Atmosoedjono et al. 1993).

Information regarding genus Coquillettidia mosquito in Indonesia is still very limited. The purposes of this paper are to provide the updated species checklist, distribution data, and identification key for female mosquitoes in the genus Coquillettidia in Indonesia.

\section{MATERIALS AND METHODS}

The checklist of Coquillettidia species in this paper is an update for the checklist of mosquito species in Indonesia as reported by O'Connor and Sopa (1981). Species records and distribution data were summarized from related references and Rikhus Vektora 2015-2018 research reports. The distribution data of the Coquillettidia mosquito in this paper is limited to the territory of Indonesia alone and excludes the territories of Malaysia Borneo and Papua New Guinea. The identification keys are arranged based on the description of the species morphological characters from various references. The mosquito morphological terms follow Harbach and Knight (1980).

\section{RESULTS AND DISCUSSION}

The checklist of Coquillettidia species and their distribution in Indonesia is presented in Table 1. In total there are 11 species of genus Coquillettidia recorded from Indonesia. The most widely distributed species is $C q$. crassipes. Papua has the greatest species diversity of Coquillettidia mosquito with seven species. Four species in the genus Coquillettidia were originally described from Indonesia, i.e., Cq. crassipes, Cq. fuscopteron, $C q$. memorans Bonne-Wepster, and Cq. nigrochracea BonneWepster.

The checklist of Coquillettidia species in this paper adds three species to the checklist compiled by O'Connor and Sopa (1981). The three species of Coquillettidia recorded in Indonesia are Cq. fuscopteron, $C q$. novochracea and Cq. xanthogaster. Coquillettidia fuscopteron and Cq. xanthogaster become new record from Papua, while Cq. novochracea was recorded from Kalimantan. Coquillettidia crassipes is newly recorded from the Lesser Sunda Islands, Cq. nigrochracea and $C q$. nigrosignata Edwards are newly recorded from Kalimantan and Cq. novochracea from Sumatra.

Coquillettidia fuscopteron was described from Digoel River, Western New Guinea (Papua). Edwards (1913) said that the name $C q$. fuscopteron was once widely accepted as a synonym of $C q$. crassipess, and also synonym with Taeniorhychus brevicellulus. In contrast, Marks (1974) who once identified this species from Merauke, Papua stated that $C q$. fuscopteron was distinct species. There was a possibility that the description of $C q$. crassipes from New Guinea morphologically has been identified as $C q$. fuscopteron.

Belkin (1962) stated the distribution of $C q$. xanthogaster is in New Hebrides (Vanuatu), New Caledonia, Loyalty Islands, and Australia (Queensland). Moreover, Assem and Bonne-Wepster (1964) has been founded the male mosquitoes of Cq. xanthogaster in New Guinea, one of which is in Koembe, Merauke. Morphologically, Cq. xanthogaster is difficult to distinguish with $C q$. crassipes (Belkin 1962), therefore both species are put in Crassipes grouped together with $C q$. aureosquammata (Marks 1974).

Coquillettida novochracea in Indonesia has been recorded in Sumatera and Kalimantan, while Rattanarithikul et al. (2006) stated that this species has been recorded from Thailand. This species was first described from Nongpoh, Assam, India by Barraud in 1927. The first discovery of Cq. novochracea was recorded in South Kalimantan (as Mansonia novochracea) written by Klokke (1961), a Dutch researcher who conducted filariasis research in Indonesia. Records in Sumatra were obtained from Lingga island, Bintan island, and Batam Island, Riau Islands Province (B2P2VRP 2018a).

Mosquito species belonging to the Crassipes group found in Indonesia including $C q$. crassipes, $C q$. aureosquammata Ludlow and Cq. xanthogaster. BonneWepster (1954) mentioned that Taeniorhynchus aureosquamatus (= Cq. aureosquammata) exists only on the Sumatra island. Moreover, Ramalingam (1974), in his 
brief survey report on Java stated that $C q$. aureosquammata is found in Java together with $C q$. crassipes and $C q$. ochracea. Record of Cq. aureosquammata from Kalimantan derived from specimen actually present in a collection maintained by units in the compound of the CDC/P3M (O'Connor and Sopa, 1981). Species Cq. aureosquammata does not yellowish in color as Coquillettidia mosquitoes in general. This species mostly dark-colored with a metallic purple and blue sparkle (Bonne-Wepster 1954).

Coquillettidia crassipes has the most extensive distribution in Indonesia. These spesies distributed in Sumatra, Kalimantan, Java, Lesser Sunda Islands, Sulawesi, Maluku, and Papua. In the world, Cq. crassipes are known to distribute across Pakistan, India, Sri Lanka, Burma, Thailand, southern China, including Hong Kong and Macau, Malaysia, Philippines, Indonesia, RyukyuRetto islands, Mariana Islands, New Guinea, Australia, and Bismarck Archipelago (Ramos et al. 2000). This species was described from Soeroelangoen, Benkoelen (now Surulangun village in South Sumatra). Discovery note of Cq. crassipes in Lesser Sunda were obtained from Karangasem District in Bali island, and Ende District in Flores island, East Nusa Tenggara Province (B2P2VRP 2016, 2017a).

The existence of Cq. giblini Taylor and $C q$. nigrosignata species had led to differences of opinion among experts. Taylor (1914) gave the name of Pseudotaeniorhynchus conopas var. giblini to the specimen from Lakekamu, Papua New Guinea. It seems that he concluded from the interpretation of Theobald (1901) of Taeniorhynchus conopas, however Edwards (1917) stated that Theobald had misidentified $T$. conopas, and he proposed the new name as Taeniorhynchus nigrosignatus. Edwards (1917) also stated that the variant described by Taylor (1914) might be different from T. nigrosignatus, so he decided that it was a separated species. Edwards (1922) examined female $T$. giblini specimen and found that there was no difference with $T$. nigrosignatus. He then confirmed that $T$. nigrosignatus as a synonymy for $T$. giblini.

The synonymy lasted about 40 years until Wharton (1962) compared specimens from Malaya and Kalimantan with a series of Mansonia (Coquillettidia) giblini specimens. Although the condition of the specimens was inadequate, Wharton could see that the Ma. giblini specimens have fewer dark marks, lines in the pleura are fainter, and there are no dark scales on the dorsum of the abdomen. Wharton concluded that the 'Ma. giblini' from the Oriental region was a different species from the New Guinea form. Accordingly, Wharton restores the name $T$. nigrosignatus (as Mansonia nigrosignata) for species from the Oriental region by the distribution in Malaya and Kalimantan. Thus, the authors deleted the record of $C q$. giblini distribution in Sumatra and Kalimantan as stated by O'Connor Sopa (1981). The reason is that the record of Cq. giblini distribution in the Oriental region is concluded as $C q$. nigrosignata. The distribution of $C q$. giblini is in Maluku and Papua (Australasian region). Distribution of Cq. nigrosignata in Sulawesi as cited by Lien et al. (1977) from Bonne-Wepster (1954) recorded as T. giblini. The discovery notes of $\mathrm{Cq}$. nigrosignata in Kalimantan were obtained from a specimen collected by CDC/P3M (O’Connor and Sopa 1981).

Coquillettidia nigrosignata is distinguished from $\mathrm{Cq}$. hodgkini Wharton by the presence of two dark lines on the dorsocentral and wider spots on the supra alar area. BonneWepster (1954) might include records of Cq. hodgkini into Cq. ochracea. Wharton (1962) described Cq. hodgkini as a new species from Lamir (Pekan), Pahang, Malaya (Malaysia), and explained its distribution in Malaya (Pahang, Perak, Selangor) and from Indonesia. But it is not said with certainty the distribution of $C q$. hodgkini in Indonesia. The discovery notes of $C q$. hodgkini in Indonesia was obtained from filariasis research conducted by Bahang et al. (1984) in Southeast Sulawesi. Apart from Sulawesi, Cq. hodgkini was also found in Kalimantan and Java based on collected specimens by CDC/P3M (O’Connor and Sopa 1981).

Knight and Stone (1977) list the distribution of $C q$. ochracea includes in Malaya, India, Thailand, Indochina, China, Japan, the Ryukyu-Retto islands, the Philippines, New Guinea and, Indonesia. In Indonesia Cq. ochracea is distributed in Sumatra, Kalimantan, Java, and Papua (Bonne-Wepster 1954). Lee et al. (1988) added the distribution of Cq. ochracea in Papua, specifically in Assike, Merauke and, Tanah Merah, and Bahang et al. (1984) stated that this species also had found in Sulawesi.

Coquillettidia memorans firstly was described from the upper Digoel River, Western New Guinea (Papua). This species has two forms that are distinguished from the color of the thoracic integument. The darker forms are only known to be found in the Digul River and Tanah Merah, Papua, while the lighter forms have been recorded in Papua New Guinea and the Cape York Peninsula. The record of Cq. memorans from Sulawesi has been stated by Brug and Bonne-Wepster (1947), however, that record did not repeated in Bonne-Wepster (1954). Steffan in 1966 stated that $C q$. memorans has only founded from New Guinea island. Thus, the authors conclude that the distribution of Cq. memorans in Indonesia is only in Papua.

The type specimen of $C q$ nigrochracea according to Bonne-Wepster (1930) No. 17.478 stored in the Medical Laboratory at Batavia, but no specimen has been seen. Lee et al. (1988) stated that Marks had been seen three specimens in KIT in 1960, in LM in 1984. One specimen from Boven Digoel, New Guinea labelled 'TYPE' and two females from Benkoelen, Sumatra labelled 'COTYPE', also one female in British Museum in 1984 with No. 15.153 from Upper Digoel River, New Guinea labelled 'Co-type' and 'Paratype'. It is decided and also stated by Lee et al. (1988) that Cq. nigrochracea has two type localities, i.e. Sumatra and Irian Jaya (Papua). The description of this species has been reported according to Lee et al. (1988) based on specimens from Sumatra. The new record of $C q$. nigrochracea in Kalimantan were obtained from the Murung Raya District, Central Kalimantan Province (B2P2VRP 2017b). 
Table 1. Species checklist and distribution of Coquillettidia mosquito species in Indonesia

\begin{tabular}{|c|c|c|c|}
\hline Valid species & Synonymy & Geographical distribution & Taxonomic remarks \\
\hline Cq. aureosquammata (Ludlow 1909) & Cq. pagei Ludlow & Sumatra, Kalimantan, Java & \\
\hline Cq. crassipes (van der Wulp 1881) & $\begin{array}{l}\text { Cq. brevicellulus } \\
\text { Theobald, } \\
\text { Cq. diaeretus Dyar, } \\
\text { Cq. pygmaeus Theobald }\end{array}$ & $\begin{array}{l}\text { Sumatra }{ }^{+}, \text {Kalimantan, Java, the } \\
\text { Lesser Sunda Islands }{ }^{\mathrm{R}} \text {, Sulawesi, } \\
\text { Moluccas, Papua }\end{array}$ & $\begin{array}{l}\text { Marks (1974) restored Cq. crassipes from synonymy with Cq. fuscopteron } \\
\text { (see Cq. fuscopteron). }\end{array}$ \\
\hline Cq. fuscopteron (Theobald 1911)* & & Papua $^{+}$ & $\begin{array}{l}\text { Cq. fuscopteron once accepted as a synonymy of } C q \text {. crassipes until Marks } \\
\text { (1974) stated that } C q \text {. fuscopteron is a distinct species. }\end{array}$ \\
\hline Cq. giblini (Taylor 1914) & & Moluccas, Papua & $\begin{array}{l}\text { Wharton (1962) restored Cq. giblini as a synonymy with Cq. nigrosignata and } \\
\text { limited its distribution in Australasian region (see Cq. nigrosignata). }\end{array}$ \\
\hline Cq. hodgkini (Wharton 1962) & & Kalimantan, Java, Sulawesi & \\
\hline Cq. memorans (Bonne-Wepster 1930) & & Papua $^{+}$ & \\
\hline $\begin{array}{l}\text { Cq. } \\
\text { 1930) }\end{array}$ & & Sumatra $^{+}$, Kalimantan ${ }^{\mathrm{R}}$, Papua $^{+}$ & $\begin{array}{l}\text { The original type specimen of Cq. nigrochracea has not been seen. Marks } \\
\text { choose two co-type (syntype) from Benkoelen, Sumatra and Upper Digoel } \\
\text { River, Papua. }\end{array}$ \\
\hline Cq. nigrosignata (Edwards 1917) & & Sumatra, Kalimantan, Sulawesi & $\begin{array}{l}\text { Edwards (1922) sunk } C q . \text { nigrosignata as a synonymy of } C q . \text { giblini. Wharton } \\
\text { (1962) restored 'oriental } C q . \text { giblini' as } C q . \text { nigrosignata. }\end{array}$ \\
\hline Cq. novochracea (Barraud 1927)* & & Sumatra $^{\mathrm{R}}$, Kalimantan & \\
\hline Cq. ochracea (Theobald 1903) & $\begin{array}{l}\text { Cq. chrysogona Knab, } \\
\text { Cq. shakujiiensis } \\
\text { Ogasawara }\end{array}$ & $\begin{array}{l}\text { Sumatra, Kalimantan, Java, } \\
\text { Sulawesi, Papua }\end{array}$ & \\
\hline Cq. xanthogaster (Edwards 1924)* & & Papua & \\
\hline
\end{tabular}

Note: ${ }^{\mathrm{R}}$ : data from Rikhus Vektora; ${ }^{+}$: type locality; *: newly added species to checklist 


\section{Identification key for female mosquito of Genus Coquillettidia in Indonesia} Modified from Rattanarithikul et al. (2006)

1. Plume (wing scales) purple or dark brown

Plume yellow or golden

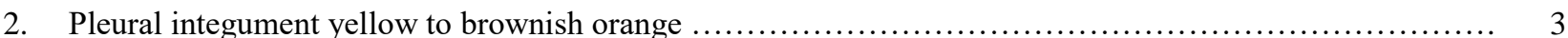

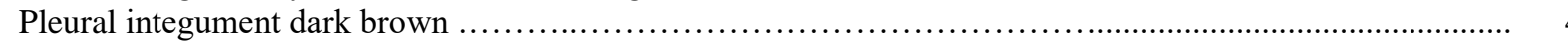

3. Scutellum bright yellow, without scales;

Terga abdomen segment 2-3 bluish purple

Cq. crassipes

Scutellum with golden yellow scales;

Terga abdomen segment 2-3 golden yellow

Cq. fuscopteron

4. Scutal integument dark, covered with creamy yellow scales;

Terga abdomen segment 3-8 metallic blue with silvery white scales in laterobasal

- $\quad$ Scutal integument brown, covered with golden yellow scales;

Terga abdomen segment 3-4 metallic purplish blue, segment 5-8 copper colored

Cq. aureosquammata

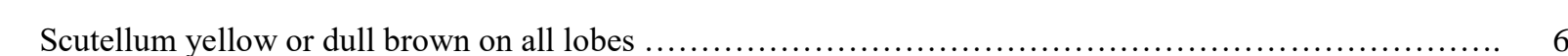

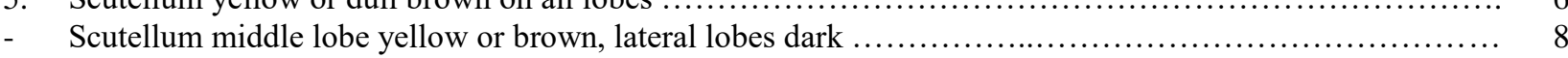

6. Scutal and pleural integument dark

Cq. nigrochracea

- Scutal and pleural integument yellow

7. Lateral scutum with brown short line in front of wing root;

Pleura with dark line from posterior margin of post-pronotum to posterior margin of mesepimeron

- Lateral scutum without brown short line in front of wing root;

Pleura without dark line from posterior margin of post-pronotum to posterior margin of mesepimeron

Cq. novochracea

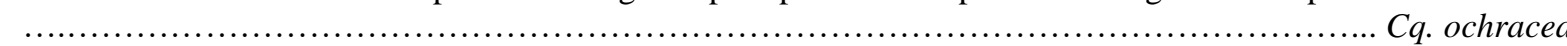

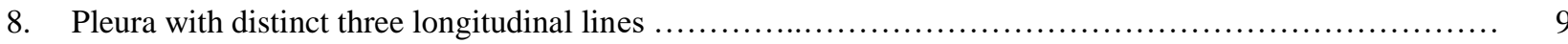

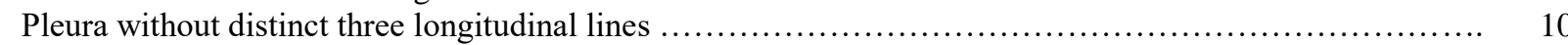

9. Terga abdomen with apical dark band on some segments;

Hind tibia with broad purplish brown basal band

Cq. nigrosignata

- $\quad$ Terga abdomen without dark bands;

Hind tibia with few dark scales on basal

Cq. giblini

10. Scutum with two pairs of dark spots above wing root;

Terga abdomen with small posterolateral dark spots on segment 3-4, sometimes on segment 2-5 ..... Cq. hodgkini

Scutum without two pairs of dark spots above wing root;

Terga abdomen with golden and dark purple scales in indistinct pattern

Cq.xanthogaster

In conclusion, Indonesia has 11 mosquito species in the genus Coquillettidia that included in one subgenus (Coquillettidia). This paper adds three species newly recorded namely, Cq. fuscopteron, Cq. novochracea and $C q$. xanthogaster. The distribution data updated for following species: Cq. crassipes (Lesser Sunda Islands), Cq. nigrochracea and Cq. nigrosignata (Kalimantan), and Cq. novochracea (Sumatra). The identification key for female Coquillettidia mosquito is provided at the end of paper.

\section{ACKNOWLEDGEMENTS}

The authors thank the Head of National Institute of Health Research and Development (NIHRD) for his permission to use Rikhus Vektora research reports to complete the data in this publication. Thanks to the Head of IVRCRD Salatiga who has provided support and facilities so that this publication can be prepared and completed. The authors also thank the IVRCRD Vector Collection and Reference Laboratory colleagues for much constructive criticisms and suggestions. 


\section{REFERENCES}

Assem VD, Bonne-Wepster J. 1964. New Guinea Culicidae: a synopsis of vectors, pests, and common species. Rijksmuseum van Natuulijke. Leiden.

Atmosoedjono S, Purnomo, Ratiwayanto S, Marwoto HA, Bangs MJ. 1993. Ecology and infection rates of natural vectors of filariasis in Tanah Intan, South Kalimantan (Borneo), Indonesia. Buletin Penelitian Kesehatan 21: 1-14.

B2P2VRP. 2016. Laporan Riset Khusus Vektor dan Reservoir Penyakit: Provinsi Nusa Tenggara Timur. Salatiga. [Indonesian]

B2P2VRP. 2017a. Laporan Riset Khusus Vektor dan Reservoir Penyakit: Provinsi Bali. Salatiga. [Indonesian]

B2P2VRP. 2017b. Laporan Riset Khusus Vektor dan Reservoir Penyakit: Provinsi Kalimantan Tengah. Salatiga. [Indonesian]

B2P2VRP. 2018a. Laporan Riset Khusus Vektor dan Reservoir Penyakit: Provinsi Kepulauan Riau. Salatiga. [Indonesian]

B2P2VRP. 2018b. Laporan Riset Khusus Vektor dan Reservoir Penyakit Provinsi Kalimantan Utara. Salatiga. [Indonesian]

Bahang Z, Saafi L, Bende N, Kirnowardoyo S, Liat LB. 1984. Malayan filariasis studies in Kendari District, Southeast Sulawesi, Indonesia. Buletin Penelitian Kesehatan 12: 8-20.

Belkin J. 1968. Mosquito studies - VII. The Culicidae of New Zealand Contrib Am Entomol Inst 3: 1-182.

Belkin JN. 1962. The mosquitoes of the South Pacific (Diptera, Culicidae). Vol. 1. University of California Press. Los Angeles.

Bonne-Wepster J. 1954. Synopsis of a hundred common non-anopheline mosquitoes of The Greater and Lesser Sundas, The Mollucas and New Guinea. Elsevier, Amsterdam.

Brug SL, Bonne-Wepster J. 1947. The geographical distribution of the mosquitoes of the Malay Archipelago. Overdruk Uit Chronica Naturae 103: 1-19.

Chiang GL, Samarawickrema WA, Mak JW, Cheong WH, Sulaiman I, Yap HH. 1986. Field and laboratory observations on Coquillettidia crassipes in relation to transmission of Brugia malayi in Peninsular Malaysia. Ann Trop Med Parasit 80: 117-121.

Edwards FW. 1913. New synonymy in Oriental Culicidae. Bull Entomo Res 221-242.

Edwards FW. 1917. Notes on Culicidae with description of new species. Notes on Culicidae. Trustees of the British Museum, London.

Edwards FW. 1922. A synopsis of adult Oriental Culicine (including Megarhinine and Sabethine) mosquitoes. Indian J Med Res 10: 249293.

Harbach RE, Kitching IJ. 1998. Phylogeny and classification of the Culicidae (Diptera). Syst Entomol 23: 327-370.

Harbach RE, Knight KL. 1980. Taxonomists' Glossary of Mosquito Anatomy. North Carolina State University, Raleigh.

Hoedojo. 1989. Vector of malaria and filariasis in Indonesia. Buletin Penelitian Kesehatan 17:180-190

Klokke AH. 1961. Filariasis due to Brugia malayi in South Borneo (Indonesia). Trans R Soc Trop Med Hyg 55: 433-439.
Knight KL, Stone A. 1977. A catalog of the mosquitoes in the world. Thomas Say Foundation \& Entomological Society of America. College Park, MD.

Lee DJ, Hicks MM, Griffiths M, Debenham ML. 1988. The Culicidae of the Australasian Region: Genus Armigeres, Bironella and Coquillettidia. In: Debenham ML (ed.). Australian Government Publishing Service. Canberra.

Lien JC, Kawengian BA, Partono F, Lami B, Cross JH. 1977. A brief survey of the mosquitoes of South Sulawesi, Indonesia, with special reference to the identity of Anopheles barbirostris (Diptera: Culicidae) from the Margolembo area. J Med Entomol 13:719-727.

Marks EN. 1974. Notes on some taxonomic characters of Culicidae. Mosquito News 6:211-213.

Njabo KY, Cornel AJ, Sehgal RNM, Loiseau C, Buermann W, Harrigan RJ, Pollinger J, et al. 2009. Coquillettidia (Culicidae, Diptera) mosquitoes are natural vectors of avian malaria in Africa. Malaria $\mathrm{J} 8$ : $1-12$.

O'Connor CT, Sopa T. 1981. A checklist of the mosquitoes of Indonesia. U.S. Naval Medical Research Unit No. 2 Jakarta.

Ramalingam S. 1974. A brief mosquito survey of Java. World Health Organization, Geneva

Ramos HC, Ribeiro H, Mitchell CJ, Novo MT, Baptista S, Sousa CA, Almeida PG, et al. 2000. On Coquillettidia crassipes, a new record for Macau, with a key to adults of the subgenera and species groups of the genus. J Am Mosq Control Assoc 16: 66-70.

Rattanarithikul R, Harrison BA, Panthusiri P, Peyton EL, Coleman RE. 2006. Illustrated keys to the mosquitoes of Thailand III. Genera Aedeomyia, Ficalbia, Mimomyia, Hodgesia, Coquillettidia, Mansonia, and Uranotaenia. Southeast Asian J Trop Med Public Health 37: 16-17.

Rattanarithikul R, Harrison BA, Pantusiri P, Coleman RE. 2005. Illustrated keys to the mosquitoes of Thailand. Southeast Asian J Trop Med Public Health 36:1-81.

Ronderos RA, Bachmann AO. 1963. A proposito del complejo Mansonia (Diptera-Culicidae). Rev Soc Entomol Argent 25: 43-51.

Steffan WA. 1966. A checklist and review of the mosquitoes of the Papuan Subregion (Diptera: Culicidae). J Med Entomol 3: 179-237.

Stone A. 1963. A synoptic catalog of the mosquitoes of the world. Supplement 2. Proc Entomol Soc Wash 65: 631-647.

Taylor FH. 1914. Culicidae from Papua. Trans R Soc Trop Med Hyg 185205.

Theobald FV. 1901. A monograph of the Culicidae of the world. Vol. 2. William Clowes and Sons Ltd., London.

Turell MJ, Dohm DJ, Sardelis MR, O’Guinn ML, Andreadis TG, Blow JA. 2005. Update on the potential of North American mosquitoes (Diptera: Culicidae) to transmit West Nile virus. J Med Entomol 42: 57-62.

Wharton RH. 1962. The biology of Mansonia mosquitoes in relation to the transmission of filariasis in Malaya. National Institute for Medical Research. Malaya. 